\title{
Perceptions towards Online Shopping: Analyzing the Greek University Students' Attitude
}

\author{
Vaggelis Saprikis, Adamantia Chouliara and Maro Vlachopoulou \\ University of Macedonia, Thessaloniki, Greece
}

\begin{abstract}
The sharp increase of Internet usage, as well as, the systematic progress of Information Technology have transformed the way goods are bought and sold, resulting to the exponential growth in the number of online shoppers. However, a lot of differences regarding online purchases have been revealed due to the various consumers' characteristics and the types of provided products and services. Therefore, understanding who are the ones consuming and why they choose to use or avoid the Internet as a distribution channel, is a vital issue for both e-commerce managers and consumer theorists. The scope of this paper is to examine the perceptions of Greek university students' adopters and non-adopters of online shopping in terms of demographic profile, expectations of online stores, advantages and problems related to online purchases. Moreover, the reasons for using or avoiding online shopping, as well as, the types of preferred products were studied. The research provides interesting insights on the online consumer behaviour, as the results show significant differences between the two groups of respondents.
\end{abstract}

Keywords: online shopping, buying behaviour, perceptions analysis, electronic business

\section{Introduction}

The Internet, as a mean for both firms and individuals to conduct business, is nowadays one of the most widely used non-store formats. According to Magee (2003), the growth in the number of online shoppers is greater than the growth in Internet users, indicating that more Internet users are becoming comfortable to shop online. Furthermore, not only does the number of adopters grow, but also the volume of their purchases is proportionally increased (Monsuwe et al, 2004). The two most commonly cited reasons for online shopping have been convenience and price (Chen and Chang, 2003). The capability of purchasing without leaving your place is of great interest to many consumers. Moreover, the use of Internet tools for price searching and comparison provides an additional advantage in consumers' final decision, as they can purchase their desired products in the lowest available price (Haubl and Trifts, 2000). On the contrary, privacy and security have been the great concerns (GrabnerKraeuter, 2002; James, 1999; Yianakos, 2002), resulting many people to browse the Internet for informational matters than for buying online (Curtis and Slater, 2000).

Regarding Greece, online shopping has been emerged quite recently as a medium for transactions between consumers and firms. A recent survey carried out from Focus BARI (2008), reported that $23 \%$ of Greek Internet users have purchased products from online stores and their population size was estimated to 690,000 people. Thus, in order to obtain a thorough point of view regarding Greek online shopping and the reason of its

Copyright (C) 2010 Vaggelis Saprikis, Adamantia Chouliara and Maro Vlachopoulou. This is an open access article distributed under the Creative Commons Attribution License unported 3.0, which permits unrestricted use, distribution, and reproduction in any medium, provided that original work is properly cited. Contact Author: Vaggelis Saprikis, e-mail: saprikis@uom.gr 
denial from quite a large group of Internet users, this study is aimed to examine the perceptions of adopters and non-adopters of online shopping in terms of demographic profile, consumers' expectations of online stores, as well as, its particular advantages and problems. It is worth mentioning that adopters are Internet users who have purchased online, while non-adopters are Internet users who have never purchased online. The study is based on previous research carried out by Teo (2006). However, it should be noted that this study is limited to the examination of expectations and perceptions of Greek university students and comprises the preliminary work of a continuous effort, which is taken place, aiming to shed light on this exponentially growing phenomenon. Research findings from this paper can be useful in order to understand university students' online buying behaviour. Additionally, by understanding the reasons why consumers buy or not buy online, online stores would be able to incorporate suitable marketing strategies, moderate consumers' concerns and convince even more people being transferred from offline to online shopping (Teo, 2006).

The paper is organized as follows. In the first section, the literature review regarding consumers' online buying behaviour and the factors that encouraging or hindering online shopping is presented. This is followed by the methodology and the results of the research. The last section concludes with the implications of the study, its limitations and directions for future research.

\section{Literature Review}

Several researchers have carried out studies in their effort to examine consumers' online buying behaviour. For example, Bellman et al (1999) investigated various predictors for whether an individual will purchase online. These authors concluded that demographic variables, such as income, education and age, have a modest impact on the decision of whether to buy online, whereas the most important determinant of online shopping was previous behaviour, such as earlier online purchases. This is consistent with Forrester Research which proved that demographic factors do not have such a high influence on technology as the consumers' attitudes do (Modahl, 2000). Kotler and Armstrong (2000) pointed out that a person's buying choices are further influenced by four key psychological factors: motivation, perception, learning and beliefs and attitude. Steinfield and Whitten (1999) suggested that the combination of the Internet, plus physical presence, provides more opportunities to capture business than the online-only presence, because they can provide better pre-purchase and post-sales services to lower consumer transaction cost and build trust in online stores. However, it is worth mentioning that beliefs and attitudes that are found in the stage prior to the adoption of e-commerce are different to those in the "post-adoption" stage (Gefen et al, 2003; Venkatesh and Brown, 2001; Yu et al, 2005).

Concerning the factors that influence or hinder online shopping, Ernst and Young (2000) reported that Internet users purchased online because of good product selection, competitive prices, and ease of use, but were concerned about shipping costs, lack of opportunity to prior examining the products, as well as, the confidentiality of credit card and personal information. Know and Lee (2003) explored consumers' concerns about payment security and its relationship to online shopping attitude and actual purchases. They observed a negative relationship between attitude towards online shopping and concerns about online payment security. Consumers with a positive attitude seem to be less concerned about payment security. Similarly, popular literature cited ease of shopping comparison, low prices, timely delivery, convenience, time saving, low shipping costs, improved customer service, tax exempt status and speedy e-mail response, as key reasons for the increase in online shopping (Lorek, 2003; Magee, 2003; Maloy, 2003; Retail Merchandiser, 2003). 
Additionally, Karayanni (2003) observed that online shoppers tend to value avoidance of queues, availability of shopping on a 24-hour basis and time efficiency. A study carried out by Monsuwe et al (2004) collectively provides all the related literature review regarding the factors that drive consumers to shop online.

As a further step, this paper encompasses the literature review regarding advantages, problems and consumers' expectations of online shopping, and examines the perceptions of adopters of online purchases compared to Internet users who preferred the traditional way of shopping.

\section{Methodology}

The research is primarily descriptive in nature, as apart from descriptive statistics, only simple statistics, namely chi-square and t-tests, were used in order to statistically compare the expectations and perceptions of adopters and non-adopters regarding online shopping. Data was collected by means of a questionnaire administered from January until March 2009 to students of Greek universities. The selection of student respondents for primary research has been successfully used in many Web-related studies, e.g. (Lee and Lin, 2005; Lee et al, 2005; Liu, 2003). However, prior to its distribution, the questionnaire was pretested in order to identify possible problems in terms of clarity and accuracy. Thus, several changes were made in order to improve the presentation of the items, based on comments and feedback. Apart from demographic-related questions, five-point Likert scale was used for all the questions concerning students' expectations and perceptions, as well as, the inquiries regarding their views associated with the advantages and the problems of online shopping. Furthermore, a set of distinct questions was applied to the two target groups in order to examine the reasons why adopters use the online stores for their purchases, whereas non-adopters avoid them. Specifically, Table 1 provides all the related literature review in which the aforementioned issues were based on.

Table 1: Scientific sources used for the survey

\begin{tabular}{|c|c|}
\hline Basic Categories of the research & Source \\
\hline Reasons for using online shopping (adopters only) & $\begin{array}{l}\text { (Bhatnagar et al, 2000; Brengman et } \\
\text { al, 2005; Chen and Chang, 2003; } \\
\text { Ernst and Young, 2000; Parasuraman } \\
\text { et al, 2005; Sin and Tse, 2002; Wee } \\
\text { and Ramachandra, 2000) }\end{array}$ \\
\hline $\begin{array}{l}\text { Reasons for not using online shopping (non-adopters } \\
\text { only) }\end{array}$ & $\begin{array}{l}\text { (Baker, 1999; Ernst and Young, } \\
\text { 2000; Furnell and Karweni, 1999; } \\
\text { Laroche et al, 2005) }\end{array}$ \\
\hline $\begin{array}{l}\text { Consumers' expectations and perceptions of online } \\
\text { stores }\end{array}$ & $\begin{array}{l}\text { (Bhatnagar et al, 2000; Choi and Lee, } \\
\text { 2003; Liao and Cheung, 2001; } \\
\text { McKnight et al, 2002; Miyazaki and } \\
\text { Fernandez, 2001; Parasuraman et al, } \\
\text { 2005; Verhagen et al, 2006) }\end{array}$ \\
\hline Advantages of online shopping & $\begin{array}{l}\text { (Alba et al, 1997; Brengman et al, } \\
\text { 2005; Eastlick and Feinberg, 1999; } \\
\text { Foucault and Scheufele 2002; } \\
\text { Karayanni, 2003) }\end{array}$ \\
\hline Problems in online stores & $\begin{array}{l}\text { (Choi and Lee, 2003; Cyr et al, 2005; } \\
\text { Know and Lee, 2003; Laroche et al, } \\
\text { 2005; McKnight et al, 2002; } \\
\text { Verhagen et al, 2006) }\end{array}$ \\
\hline
\end{tabular}




\section{Results}

The survey results are organized as follows. In the first section, the demographic analysis is presented. This is followed by the reasons for buying (adopters) or not buying online (non-adopters), as well as, the types of purchased and interested products/services. The third section concludes with consumers' expectations and perceptions regarding online shopping, whereas the last two sections are referred to the advantages and problems of online purchases.

\subsection{Demographic characteristics}

A total of 427 respondents comprised the population of interest, where 220 (51.5\%) have purchased online at least one time in the past, whereas $207(48.5 \%)$ preferred to purchase from traditional stores (Table 2). Specifically, adopters were mainly males and most of them $(29.6 \%)$ attending the fourth year of their undergraduate studies (seniors), whereas non-adopters were females in the third or the fourth year of their studies (juniors or seniors). However, it is worth to be mentioned that graduate students were the most receptive adoption category, as a high percentage of them $(80.4 \%)$ were using the Internet in order to purchase online.

Regarding their years of Internet activity, adopters were normally more experienced in using the Internet than non-adopters, as they had more years of involvement. Furthermore, they spent much more hours daily in front of a personal computer or surfing the Net, explaining in a way that their greater familiarity with computer technology leading them to being more receptive to alternative methods of traditional shopping. However, a small number of annual online purchases were recorded, as a high percentage of adopters $(41.8 \%)$ were purchasing only $2-3$ products every year. On the contrary, it is worth to be mentioned that only $3.3 \%$ of non-adopters intent to buy online this year. This scarce percentage is remarkably noticeable as many Internet users are moving annually from traditional to online shopping (Magee, 2003). Their refusal can be explained by their ignorance to online methods of shopping, their preference to buy from traditional stores and reasons related to security matters.

Concerning chi-square statistics, a significant association was observed in all tests between adopters/non-adopters and demographic characteristics. Specifically, in the inquiries regarding the years of using the Internet, as well as, the daily usage of personal computer and the Internet, an extremely high significant association was examined. Moreover, based on the odds ratio, it was detected that an adopter was 2.86 times more likely to be a man than a woman (Field, 2005). 
Table 2: Demographic characteristics of the sample

\begin{tabular}{|c|c|c|c|c|c|}
\hline \multirow[b]{2}{*}{ Demographic profile } & \multicolumn{2}{|c|}{ Adopters } & \multicolumn{2}{|c|}{ Non adopters } & \multirow[b]{2}{*}{ Chi - Square } \\
\hline & No & $\%$ & No & $\%$ & \\
\hline \multicolumn{6}{|l|}{ Gender } \\
\hline Male & 134 & $60.9 \%$ & 73 & $35.3 \%$ & $\mathrm{df}=1$ \\
\hline Female & 86 & $39.1 \%$ & 134 & $64.7 \%$ & $\begin{aligned} \text { chi-sq } & =28.079 \\
\mathrm{p} & \approx 0.000\end{aligned}$ \\
\hline \multicolumn{6}{|l|}{ Rank at university } \\
\hline Freshmen & 29 & $13.2 \%$ & 25 & $12.2 \%$ & $\mathrm{df}=4$ \\
\hline Sophomores & 43 & $19.5 \%$ & 52 & $25.1 \%$ & chi-sq $=34.303$ \\
\hline Juniors & 42 & $19.1 \%$ & 51 & $24.6 \%$ & $\mathrm{p} \approx 0.000$ \\
\hline Seniors & 65 & $29.6 \%$ & 69 & $33.3 \%$ & \\
\hline Graduate student & 41 & $18.6 \%$ & 10 & $4.8 \%$ & \\
\hline \multicolumn{6}{|c|}{ Daily usage of personal computer } \\
\hline 1 hour and below & 10 & $4.5 \%$ & 32 & $15.5 \%$ & $\mathrm{df}=4$ \\
\hline 1-3 hours & 46 & $20.9 \%$ & 80 & $38.6 \%$ & chi-sq $=39.549$ \\
\hline 3.1-5 hours & 72 & $32.7 \%$ & 47 & $22.7 \%$ & $\mathrm{p} \approx 0.000$ \\
\hline 5.1-7 hours & 51 & $23.3 \%$ & 25 & $12.1 \%$ & \\
\hline 7 hours and above & 41 & $18.6 \%$ & 23 & $11.1 \%$ & \\
\hline \multicolumn{6}{|c|}{ Daily usage of the Internet } \\
\hline 1 hour and below & 18 & $8.2 \%$ & 58 & $28.0 \%$ & $\mathrm{df}=4$ \\
\hline 1-3 hours & 63 & $28.6 \%$ & 75 & $36.2 \%$ & chi-sq $=41.941$ \\
\hline 3.1-5 hours & 67 & $30.5 \%$ & 39 & $18.9 \%$ & $\mathrm{p} \approx 0.000$ \\
\hline 5.1-7 hours & 44 & $20.0 \%$ & 21 & $10.1 \%$ & \\
\hline 7 hours and above & 28 & $12.7 \%$ & 14 & $6.8 \%$ & \\
\hline \multicolumn{6}{|c|}{ Years of using the Internet } \\
\hline $1-3$ years & 49 & $22.3 \%$ & 81 & $39.1 \%$ & $\mathrm{df}=3$ \\
\hline 4-6 years & 73 & $33.2 \%$ & 80 & $38.7 \%$ & chi-sq $=52.677$ \\
\hline $7-9$ years & 67 & $30.4 \%$ & 37 & $17.9 \%$ & $\mathrm{p} \approx 0.000$ \\
\hline 10 years and above & 31 & $14.1 \%$ & 9 & $4.3 \%$ & \\
\hline
\end{tabular}

\begin{tabular}{lll}
\hline Frequency of online purchases & & \\
About once every year & 44 & $20.0 \%$ \\
2-3 purchases annually & 92 & $41.8 \%$ \\
4-5 purchases annually & 35 & $15.9 \%$ \\
6-8 purchases annually & 27 & $12.3 \%$ \\
9 purchases and above annually & 22 & $10.0 \%$ \\
\hline
\end{tabular}

\section{Intend to buy online this year}

Absolutely No

Probably No

I do not know yet

Probably Yes

Absolutely Yes

4.2 Reasons for buying (adopters) or not buying online (non-adopters) Types of purchased/interested products and services

$\begin{array}{rr}109 & 52.7 \% \\ 67 & 32.4 \% \\ 24 & 11.6 \% \\ 4 & 1.9 \% \\ 3 & 1.4 \%\end{array}$

Regarding adopters, the main reasons for using the online stores were the lower prices compared to traditional stores (82.3\%), the easement of online buying procedures 
$(68.2 \%)$ and the wide variety of available products (45.9\%) - (Table 3). Computer hardware/software (68.2\%) and travel tickets $(57.7 \%)$ were the most commonly purchased categories of products, followed by consumer electronics (46.4\%), CDs/DVDs $(25 \%)$ and books $(19.5 \%)$ (Table 4). However, it is worth to be mentioned that considerably high percentages of future buying intention were recorded in almost all types of products regarding respondents who had purchased online other types of products, especially concerning categories, such as jewellery \& watches and food \& drink, where low levels of initial online adoption were recorded. This intention can be explained by adopters' generally positive attitude towards e-shopping.

On the other hand, non-adopters' main reasons for not buying online (Table 3) were security and privacy concerns (55\%), their need to physically examine the products $(53.2 \%)$ and their preference to purchase from brick-and-mortal stores (51.4\%), whereas a large group of them (40.9\%) mentioned that they did not bought online because they did not use credit cards for their payments. Besides, a considerable number of non-adopters reported that they had visited or searched the online stores for informational matters (32.4\%) and expressed their future intention to buy online (Table 4). These reports are of great interest as positive responses were recorded in the majority of the provided types of products. As a consequence, the reasons mentioned in Table 3 forced them to limit their visit to online stores in checking products and pricing, before going to a brickand-mortal store for shopping.

Table 3: Reasons for buying (adopters) or not buying online (non-adopters)

\begin{tabular}{|c|c|c|c|c|c|}
\hline \multirow{2}{*}{\begin{tabular}{|l|}
$\begin{array}{c}\text { Reasons for not } \\
\text { adopting the online } \\
\text { purchases }\end{array}$ \\
$\begin{array}{l}\text { Security and privacy } \\
\text { reasons }\end{array}$ \\
\end{tabular}} & \multicolumn{2}{|c|}{ Non-adopters } & \multirow{2}{*}{$\begin{array}{l}\text { Reasons for adopting } \\
\text { the online purchases }\end{array}$} & \multicolumn{2}{|c|}{ Adopters } \\
\hline & 121 & $55.0 \%$ & & 181 & $82.3 \%$ \\
\hline $\begin{array}{l}\text { Need to physically } \\
\text { examine the product }\end{array}$ & 117 & $53.2 \%$ & $\begin{array}{l}\text { Easement of online } \\
\text { buying procedures }\end{array}$ & 150 & $68.2 \%$ \\
\hline $\begin{array}{l}\text { Prefer to buy from } \\
\text { brick-and-mortal stores }\end{array}$ & 113 & $51.4 \%$ & Wide variety of products & 101 & $45.9 \%$ \\
\hline $\begin{array}{l}\text { Do not use a } \\
\text { credit card }\end{array}$ & 90 & $40.9 \%$ & Various payment options & 51 & $23.2 \%$ \\
\hline $\begin{array}{l}\text { Are unaware of the } \\
\text { buying procedure } \\
\text { through the Internet }\end{array}$ & 35 & $15.9 \%$ & High quality of products & 33 & $15.0 \%$ \\
\hline Shipping delays & 30 & $13.6 \%$ & Other reasons & 18 & $8.2 \%$ \\
\hline $\begin{array}{l}\text { Unaffordable } \\
\text { transportation fees }\end{array}$ & 28 & $12.7 \%$ & & & \\
\hline Other reasons & 6 & $2.7 \%$ & & & \\
\hline
\end{tabular}


Table 4: Types of product/services

\begin{tabular}{|c|c|c|c|c|c|c|c|c|}
\hline & \multicolumn{4}{|c|}{ Adopters } & \multicolumn{4}{|c|}{ Non-adopters } \\
\hline $\begin{array}{l}\text { Types of } \\
\text { products/servi }\end{array}$ & \multicolumn{2}{|c|}{ Bought } & \multicolumn{2}{|c|}{$\begin{array}{l}\text { Intend to } \\
\text { buy in the } \\
\text { future: }\end{array}$} & \multicolumn{2}{|c|}{$\begin{array}{c}\text { Searched } \\
\text { information } \\
\text { for: }\end{array}$} & \multicolumn{2}{|c|}{$\begin{array}{l}\text { Intend to } \\
\text { buy in the } \\
\text { future: }\end{array}$} \\
\hline $\begin{array}{l}\text { Computer } \\
\text { hardware \& } \\
\text { software }\end{array}$ & $\begin{array}{c}15 \\
0\end{array}$ & $\begin{array}{c}68.2 \\
\%\end{array}$ & 72 & $\begin{array}{c}32.7 \\
\%\end{array}$ & 83 & $\begin{array}{c}40.1 \\
\%\end{array}$ & 69 & $33.3 \%$ \\
\hline Travel & $\begin{array}{c}12 \\
7\end{array}$ & $\begin{array}{c}57.7 \\
\%\end{array}$ & 80 & $\begin{array}{c}36.4 \\
\%\end{array}$ & 93 & $\begin{array}{c}44.9 \\
\%\end{array}$ & 99 & $47.8 \%$ \\
\hline $\begin{array}{l}\text { Consumer } \\
\text { electronics }\end{array}$ & $\begin{array}{c}10 \\
2\end{array}$ & $\begin{array}{c}46.4 \\
\%\end{array}$ & 80 & $\begin{array}{c}36.4 \\
\%\end{array}$ & 83 & $\begin{array}{c}40.1 \\
\%\end{array}$ & 77 & $37.2 \%$ \\
\hline CDs \& DVDs & 55 & $\begin{array}{c}25.0 \\
\%\end{array}$ & 50 & $\begin{array}{c}22.7 \\
\%\end{array}$ & 117 & $\begin{array}{c}56.5 \\
\%\end{array}$ & 46 & $22.2 \%$ \\
\hline Books & 43 & $\begin{array}{c}19.5 \\
\%\end{array}$ & 70 & $\begin{array}{c}31.8 \\
\%\end{array}$ & 103 & $\begin{array}{c}49.8 \\
\%\end{array}$ & 41 & $19.8 \%$ \\
\hline $\begin{array}{l}\text { Clothing \& } \\
\text { accessories }\end{array}$ & 30 & $\begin{array}{c}13.6 \\
\%\end{array}$ & 65 & $\begin{array}{c}29.5 \\
\%\end{array}$ & 92 & $\begin{array}{c}44.4 \\
\%\end{array}$ & 42 & $20.3 \%$ \\
\hline $\begin{array}{l}\text { Health \& } \\
\text { beauty }\end{array}$ & 16 & $7.3 \%$ & 39 & $\begin{array}{c}17.7 \\
\%\end{array}$ & 72 & $\begin{array}{c}34.8 \\
\%\end{array}$ & 25 & $12.1 \%$ \\
\hline $\begin{array}{l}\text { Jewellery \& } \\
\text { watches }\end{array}$ & 13 & $5.9 \%$ & 40 & $\begin{array}{c}18.2 \\
\%\end{array}$ & 73 & $\begin{array}{c}35.3 \\
\%\end{array}$ & 30 & $14.5 \%$ \\
\hline Food \& drink & 8 & $3.6 \%$ & 33 & $\begin{array}{c}15.0 \\
\%\end{array}$ & 61 & $\begin{array}{c}29.5 \\
\%\end{array}$ & 11 & $5.3 \%$ \\
\hline Others & 39 & $\begin{array}{c}17.7 \\
\%\end{array}$ & 36 & $\begin{array}{c}16.4 \\
\%\end{array}$ & 56 & $\begin{array}{c}27.1 \\
\%\end{array}$ & 24 & $11.6 \%$ \\
\hline
\end{tabular}

\subsection{Consumers' expectations and perceptions regarding online shopping}

Consumers' expectations and perceptions were examined in terms of general expectations and perceptions relating to privacy policy and online shopping risk (Table 5). Concerning general expectations, the mean scores on non-adopters are quite the same compared to adopters, demonstrating that both of them generally had common expectations from online stores. As a consequence, t-tests values do not reveal statistically significant differences in all inquiries between the two groups of respondents.

Regarding their perceptions on privacy policy, non-adopters had slower mean scores than adopters, demonstrating that the former were more concerned about privacy issues. However, it was observed that this category of questions had the slowest scores of all, indicating that security and privacy were of great concern in both target groups.

With reference to online shopping risk, for almost all the inquiries, adopters had higher scores than non-adopters, indicating the positive impact of these issues to their perceptions about risk reduction. However, the existence of a brick-and-moral shop, apart from the online store, had slightly higher influence on non-adopters, explaining that their mistrust was greatly based on the absence of a specific place where they can physically contact. Furthermore, this question scored the highest on non-adopters' responses. 
Table 5: Consumers' expectations and perceptions regarding online stores

\begin{tabular}{|c|c|c|c|}
\hline General expectations & $\begin{array}{l}\text { Non-adopters } \\
\text { Mean (SD) }\end{array}$ & $\begin{array}{l}\text { Adopters } \\
\text { Mean (SD) }\end{array}$ & $\begin{array}{l}\text { t-test } \\
\text { value }\end{array}$ \\
\hline $\begin{array}{l}\text { Online stores should provide sufficient } \\
\text { information about available products }\end{array}$ & $4.62(0.77)$ & $4.66(0.80)$ & -0.60 \\
\hline Online stores should have a good reputation & $4.46(0.85)$ & $4.43(0.82)$ & 0.40 \\
\hline $\begin{array}{l}\text { Online stores should provide adequate } \\
\text { payment options }\end{array}$ & $4.54(0.80)$ & $4.45(0.88)$ & 1.06 \\
\hline $\begin{array}{l}\text { Online stores should offer sufficient number of } \\
\text { value added services }\end{array}$ & $4.59(0.83)$ & $4.65(0.75)$ & -0.73 \\
\hline $\begin{array}{l}\text { Online stores should provide contact options, } \\
\text { like telephone numbers and forms to their } \\
\text { customers }\end{array}$ & $4.63(0.77)$ & $4.59(0.74)$ & 0.57 \\
\hline \multicolumn{4}{|l|}{ Perceptions on privacy policy } \\
\hline $\begin{array}{l}\text { Online stores use sufficient security mechanisms } \\
\text { to ensure the privacy of consumers' data }\end{array}$ & $3.06(1.24)$ & $3.55(1.06)$ & $-4.46^{\mathrm{a}}$ \\
\hline $\begin{array}{l}\text { Online stores use consumers' data for statistic } \\
\text { issues without consent }\end{array}$ & $3.08(1.33)$ & $3.19(1.37)$ & -0.83 \\
\hline $\begin{array}{l}\text { Online stores ask for consumers' permission in } \\
\text { order to send advertisements to their e-mail } \\
\text { accounts }\end{array}$ & $3.12(1.37)$ & $3.47(1.35)$ & $-2.67^{c}$ \\
\hline $\begin{array}{l}\text { Online stores forward consumers' information to } \\
\text { marketing companies }\end{array}$ & $2.80(1.32)$ & $2.97(1.42)$ & -1.32 \\
\hline \multicolumn{4}{|l|}{$\begin{array}{l}\text { Perceptions regarding online shopping risk. } \\
\text { Risk is diminished when: }\end{array}$} \\
\hline $\begin{array}{l}\text { Consumers can return a product and get refunded } \\
\text { the purchase price }\end{array}$ & $3.74(1.27)$ & $3.95(1.18)$ & -1.78 \\
\hline $\begin{array}{l}\text { Security mechanisms are used to ensure personal } \\
\text { data safety }\end{array}$ & $3.87(1.14)$ & $3.93(1.09)$ & -0.53 \\
\hline The company has also brick-and-mortal stores & $3.90(1.11)$ & $3.89(1.02)$ & 0.17 \\
\hline $\begin{array}{l}\text { Online stores offer guarantee for their } \\
\text { provided products }\end{array}$ & $3.80(1.16)$ & $4.16(1.01)$ & $-3.45^{b}$ \\
\hline
\end{tabular}

\subsection{Advantages of online shopping}

Generally, the advantages of online shopping do influence the consumers' buying behaviour. In particular, regarding our survey, the results indicate that adopters perceived the positive impact of online shopping to a higher degree compared to non-adopters (Table 6). Specifically, the formers felt that the Internet provides them with the ability to shop abroad and purchase any time of the day. Additionally, it makes them easy to find real bargains or compare shopping across different websites or within a particular website as well. Of lesser importance are the time saving and the advantage of having more time to evaluate and select a product. However, it is worth mentioning that t-tests values reveal statistically significant differences in almost half of the inquiries in which the two target groups responded. 
Table 6: Advantages of online shopping

\begin{tabular}{|l|c|c|c|}
\hline Advantages of online shopping & $\begin{array}{c}\text { Non-adopters } \\
\text { Mean (SD) }\end{array}$ & $\begin{array}{c}\text { Adopters } \\
\text { Mean (SD) }\end{array}$ & $\begin{array}{c}\text { t-test } \\
\text { value }\end{array}$ \\
\hline Shop any time of the day & $4.54(0.91)$ & $4.61(0.87)$ & $-0.79^{\mathrm{b}}$ \\
\hline Shop abroad & $4.55(0.87)$ & $4.65(0.80)$ & -1.34 \\
\hline Save time & $3.99(1.17)$ & $4.09(1.13)$ & -0.91 \\
\hline $\begin{array}{l}\text { Easy to do comparison shopping between } \\
\text { products, as well as, online stores }\end{array}$ & $4.00(1.02)$ & $4.20(0.96)$ & $-2.19^{\mathrm{d}}$ \\
\hline $\begin{array}{l}\text { More easily you can find a product compared to } \\
\text { brick-and-mortal stores }\end{array}$ & $3.89(1.00)$ & $4.00(1.06)$ & -1.07 \\
\hline $\begin{array}{l}\text { Have more options compared to } \\
\text { brick-and-mortal stores }\end{array}$ & $3.74(1.04)$ & $3.87(1.06)$ & -1.27 \\
\hline Easy to find real bargains & $4.08(0.94)$ & $4.20(0.91)$ & -1.42 \\
\hline $\begin{array}{l}\text { Provided products are cheaper compared to } \\
\text { brick-and-mortal stores }\end{array}$ & $3.86(1.05)$ & $4.07(0.97)$ & $-2.13^{\mathrm{d}}$ \\
\hline $\begin{array}{l}\text { The whole buying procedure is more easily } \\
\text { compared to brick-and-mortal stores }\end{array}$ & $3.20(1.20)$ & $3.60(1.19)$ & $-3.44^{\mathrm{b}}$ \\
\hline $\begin{array}{l}\text { Consumers can find products that there are not } \\
\text { in brick-and-mortal stores }\end{array}$ & $3.85(1.07)$ & $3.95(1.07)$ & -1.01 \\
\hline $\begin{array}{l}\text { Have much more time to evaluate and } \\
\text { select a product }\end{array}$ & $3.77(1.12)$ & $4.08(1.07)$ & $-2.92^{\mathrm{b}}$ \\
\hline
\end{tabular}

\subsection{Problems in online shopping}

In our survey, the problems of online shopping were classified in two categories; general problems and after-sales problems. In both of them, statistically significant differences were identified between adopters and non-adopters in all inquiries (Table 7). Particularly, the mean scores of the latter were higher, indicating that non-adopters perceived online shopping problems as greater barriers to their online purchase intention. Results relating to general problem perceptions indicate that non-adopters were more concern about the possibility of having their credit card data intercepted, the difficulty to confirm the reliability of the provided products and the possibility to buy a product that it would not value as much as they pay for it. Concerning after-sales problems, they strongly believed that it is difficult to have a defective product changed with a new one and that products' guarantee are not assured. Commonly, adopters had quite the same concerns, however their mean scores were much slower, demonstrating that the problems of online shopping can not influence such a high their online shopping intentions. 
Table 7: Problems in online shopping

\begin{tabular}{|c|c|c|c|}
\hline Problems relating to online stores in general & $\begin{array}{l}\text { Non-adopters } \\
\text { Mean (SD) }\end{array}$ & $\begin{array}{l}\text { Adopters } \\
\text { Mean (SD) }\end{array}$ & $\begin{array}{l}\text { t-test } \\
\text { value }\end{array}$ \\
\hline $\begin{array}{l}\text { Online stores promise more than they can } \\
\text { practically offer }\end{array}$ & $3.43(0.95)$ & $2.95(1.00)$ & $5.03^{a}$ \\
\hline Consumers can not completely trust them & $3.80(1.10)$ & $3.33(1.12)$ & $4.43^{\mathrm{a}}$ \\
\hline $\begin{array}{l}\text { Online stores are not always official } \\
\text { representatives of their offered products }\end{array}$ & $3.55(0.99)$ & 3.05 (1.09) & $4.95^{\mathrm{a}}$ \\
\hline $\begin{array}{l}\text { Consumers find it difficult to confirm the } \\
\text { reliability of the provided products }\end{array}$ & $3.98(1.04)$ & $3.31(1.08)$ & $6.46^{\mathrm{a}}$ \\
\hline $\begin{array}{l}\text { It is possible to have your credit card } \\
\text { data intercepted }\end{array}$ & $4.10(1.03)$ & $3.50(1.14)$ & $5.72^{a}$ \\
\hline $\begin{array}{l}\text { It is possible to buy a product that it would not } \\
\text { value as much as you pay for it }\end{array}$ & $3.97(1.00)$ & $3.47(1.06)$ & $5.00^{\mathrm{a}}$ \\
\hline \multicolumn{4}{|l|}{ After-sales Problems } \\
\hline $\begin{array}{l}\text { Online stores can keep customers' money and } \\
\text { do not send the agreed product }\end{array}$ & $3.29(1.17)$ & $2.77(1.11)$ & $4.72^{\mathrm{a}}$ \\
\hline $\begin{array}{l}\text { It is difficult to change a defective product with } \\
\text { a new one }\end{array}$ & $3.65(0.98)$ & $3.14(1.09)$ & $5.15^{\mathrm{a}}$ \\
\hline It s difficult to have after-sales services & $3.48(0.91)$ & $3.24(1.03)$ & $2.57^{\mathrm{a}}$ \\
\hline $\begin{array}{l}\text { It is difficult to get answers to your queries from } \\
\text { the online stores after your purchases }\end{array}$ & $3.31(0.94)$ & $2.80(1.04)$ & $5.40^{\mathrm{a}}$ \\
\hline Product's guarantee is not assured & $3.50(1.00)$ & $2.85(1.04)$ & $6.49^{\mathrm{a}}$ \\
\hline $\begin{array}{l}\text { The delivery of the purchased product is } \\
\text { time-consuming }\end{array}$ & $3.14(1.10)$ & $2.60(1.10)$ & $5.01^{\mathrm{a}}$ \\
\hline
\end{tabular}

\section{Conclusion}

This paper comprises the first part of an ongoing research aiming to shed light on the broad topic of online shopping. Particularly, its scope was to examine the expectations and perceptions of Greek university students regarding online shopping. The study provides interesting insights on the online consumer behaviour, as the results showed significant differences between the two groups of respondents. Generally, adopters had higher expectations from online shopping on issues relating to privacy policy and risk. However, much greatly significant difference was identified between adopters and non-adopters regarding their particular perceptions on advantages and problems of online shopping. Findings of this research could help firms better understand their particular needs and consequently, analogous marketing policies could be applied, as the better understanding of online consumer behaviour, the more advantageous a firm could be on the boundless market of online shopping.

On the contrary, despite the fact that the results provide meaningful implications, the research has four limitations. Firstly, it is restricted to university students. Secondly, only simple statistics, namely t-tests and chisquare, have been used. Thirdly, the results were not compared with analogous findings in other countries and lastly, it is primarily descriptive in nature, as it has not offered any kind of proposed framework or model. For future research, the questionnaire is going to be distributed with no Internet users' restrictions; and more advanced statistical methodologies are going to be applied, in order to examine the possible differences between the two target groups, as well as, modelling sample's responses. 
Additionally, the results are going to be compared with analogous studies which have taken place in other countries in order to provide the differences and the similarities of consumers' online shopping perceptions and expectations.

\section{References}

Alba, J., Lynch, J., Weitz, B., Janizszewski, C., Lutz, R., Sawyer, A. and Wood, S. (1997) 'Interactive home shopping: consumer, retailer, and manufacturer incentives to participate in electronic marketplaces,' Journal of Marketing, 61 (3), 38-53.

Baker, C. R. (1999) 'An analysis of fraud on the Internet,' Internet Research: Electronic Networking Applications and Policy, 9 (5), 348-359.

Bellman, S., Lohse, G. and Johnson, E. (1999) 'Predictors of online buying behaviour,' Communications of the ACM, 42 (12), 32-38.

Bhatnagar, A., Misra, S. and Rao, H. R. (2000) 'On risk, convenience, and internet shopping behaviour - why some consumers are online shoppers while others are not,' Communications of the ACM, 43 (11), 98-105.

Brengman, M., Guens, M., Weijters, B., Smith, S. M. and Swinyard, W. R. (2005) 'Segmenting internet shoppers based on their web-usagerelated lifestyle: a cross-cultural validation,' Journal of Business Research, 58 (1), 79-88.

Chen, S. J. and Chang, T. Z. (2003) 'A descriptive model of online shopping process: some empirical results,' International Journal of Service Industry Management, 14 (5), 556-569.

Choi, J. and Lee, K. H. (2003) 'Risk perception and e-shopping: a cross-cultural study,' Journal of Fashion Marketing and Management, 7 (1), 49-64.

Curtis, J. and Slater, R. (2000) 'Cars set for online sales boom,' Marketing, 10, February, 22-23.
Cyr, D., Bonanni, C., Bowes, J. and Ilsever, J. (2005) 'Beyond trust: website design preferences across cultures,' Journal of Global Information Management, 13 (4), 24-52.

Eastlick, M. A. and Feinberg, R. A. (1999) 'Shopping motives for mail catalog shopping,' Journal of Business Research, 45 (3), 281-291.

Ernst and Young (2000), 'Global Online Retailing,' [Online], [Retrieved January 27, 2003], http://www.ey.com

Field, A. P. (2005) Discovering statistics using SPSS ( $2^{\text {nd }}$ ed.), London: Sage publications.

Focus BARI (2008) 'The Greek e-consumer 2008,' [Online], [Retrieved April 17, 2009], http://www.focus.gr/default.asp?id=300160 022\&lcid=1032 (in Greek)

Foucault, B. E. and Scheufele, D. A. (2002) 'Web versus campus store? Why students buy textbook online,' Journal of Consumer Marketing, 19 (5), 409-423.

Furnell, S. M. and Karweni, T. (1999) 'Security implications of electronic commerce: a survey of consumers and business,' Internet Research: Electronic Networking Applications and Policy, 9 (5), 372-382.

Gefen, D., Karahanna, E. and Straub, D. W. (2003) 'Inexperience and experience with online stores: the importance of TAM and trust,' IEEE Transactions on Engineering Management, 50 (3), 307-321.

Grabner-Kraeuter, S. (2002) 'The role of consumers' trust in online-shopping,' Journal of Business Ethics, 39 (1), 43-51.

Haubl, G. and Trifts, V. (2000) 'Consumer decision making in online shopping environments: the effects of interactive decision aids,' Marketing Science, 19 (1), 421.

James, D. (1999) 'From clicks to coin,' Marketing News, 33 (21), 3. 
Karayanni, D. A. (2003) 'Web-shoppers and non-shoppers: compatibility, relative advantage and demographics,' European Business Review, 15 (3), 141-152.

Know, K. and Lee, J. (2003) 'Concerns about payment security of Internet purchases: a perspective on current on-line shoppers,' Clothing and Textiles Research Journal, 21 (4), 174-184.

Kotler, P. and Armstrong, G. (2000) Marketing ( $5^{\text {th }}$ ed.), Prentice-Hall: Englewood Cliffs, NJ.

Laroche, M., Yang, Z., McDougall, G. H. G. and Bergeron, J. (2005) 'Internet versus bricks and mortar retailers: an investigation into intangibility and its consequences,' Journal of Retailing, 81 (4), 251-267.

Lee, G. and Lin, H. (2005) 'Customer Perceptions of E-service quality in online shopping,' International Journal of Retail and Distribution Management, 33 (2), 161-176.

Lee, S., Katerattanakul, P. and Hong, S. (2005) 'Framework for User Perception of Effective E-tail Web Sites,' Journal of Electronic Commerce in Organizations, 3 (1), 13-34.

Liao, Z. and Cheung, M. T. (2001) 'Internetbased e-shopping and consumer attitudes: an empirical study,' Information and Management, 38 (5), 299-306.

Liu, Y. (2003) 'Developing a Scale to Measure the Interactivity of Web Sites,' Journal of Advertising Research, 43 (6), 207-216.

Lorek, L. A. (2003) 'Buyers catch on to online shopping,' San Antonio Express-News. [Online], [Retrieved December 22, 2003], http://web.lexis-

nexis.com/universe/document

Magee, M. (2003) 'Boom or bust for eshopping,' The Sunday Tribune. [Online], [Retrieved December 22, 2003], http://web.lexis-

nexis.com/universe/document

Maloy, T. K. (2003) 'Net is here to stay for retailers,' [Online], [Retrieved December 22, 2003], http://web.lexisnexis.com/universe/document

McKnight, D. H., Choudhury, V. and Kacmar, C. (2002) 'Developing and validating trust measures for e-commerce: an integrative typology,' Information Systems Research, 13 (3), 334-359.

Miyazaki, A. D. and Fernandez, A. (2001) 'Consumer perceptions of privacy and security risks for online shopping,' The Journal of Consumer Affairs, 35 (1), 27-44.

Modahl, M. (2000) Now or Never: How Companies Must Change to Win the Battle for the Internet Consumer, Harper Business: New York, NY.

Monsuwe, T. P., Dellaert, B. and Ruyter, K. (2004) 'What drives consumers to shop online A literature review,' International Journal of Service Industry Management, 15 (1), 102-121.

Parasuraman, A., Zeithaml, V. A. and Malhotra, A. (2005) 'E-S-Qual: a multipleitem scale for assessing electronic service quality,' Journal of Service Research, 7 (3), 213-233.

Retail Merchandiser (2003) 'Online spending jumps 18 per cent,' Retail Merchandiser. [Online], [Retrieved December 22, 2003], http://web.lexis-

nexis.com/universe/document

Sin, L. and Tse, A. (2002) 'Profiling internet shoppers in Hong Kong: demographic, psychographic, attitudinal and experiential factors,' Journal of Interactive Marketing, 15 (1), 7-29.

Steinfield, C. and Whitten, P. (1999) 'Community level socio-economic impacts of electronic commerce,' Journal of Computer- 
mediated Communication, 5 (2). [Online], [Retrieved June 1, 2009], http://jcmc.indiana.edu/vol5/issue2/steinfie ld.html

Teo, T. (2006) 'To buy or not to buy online: adopters and non-adopters of online shopping in Singapore,' Behaviour \& Information Technology, 25 (6), 497-509.

Verhagen, T., Meents, S. and Tan, Y. (2006) 'Perceived Risk and Trust Associated with Purchasing at Electronic Marketplaces,' in Serie Research Memoranda 0001, Faculty of Economics, Business Administration and Econometrics, Free University of Amsterdam, Amsterdam, Netherlands.

Venkatesh, V. and Brown, S. A. (2001) 'A longitudinal investigation of personal computers in homes: adoption determinants and emerging,' MIS Quarterly, 25 (1), 71-102.

Wee, K. N. L. and Ramachandra, R. (2000) 'Cyberbuying in China, Hong Kong and Singapore: tracking the who, where, why and what of online buying,' International Journal of Retail \& Distribution Management, 28 (7), 307-316.

Yianakos, C. (2002) 'Nameless in cyberspace: protecting online privacy,' Journal of Banking and Financial Services, 116 (6), 48-49.

Yu, J., Ha, I., Choi, M. and Rho, J. (2005) 'Extending the TAM for a t-commerce,' Information \& Management, 42 (77), 965976. 